\title{
ROLES REVERSED IN THE END OF THIS DAY'S BUSINESS BY KATHARINE BURDEKIN: A UTOPIAN DYSTOPIAN SOCIAL ORDER
}

\author{
Emrah Atasoy \\ (Hacettepe University, Ankara, Turkey)
}

\begin{abstract}
This article aims to introduce the British writer, Katharine Burdekin as a writer of speculative fiction and to critically deal with her literary utopia/dystopia, The End of This Day's Business (1935, 1989). Burdekin's brief biographical information, in conjunction with an analysis of her other significant work, Swastika Night (1937) is necessary for comprehending her concerns about the future and her utopian impulse. The article presents an analytical approach to the interconnectedness between gender politics, knowledge production and communication, and practice of power in the envisioned world order. It concerns Burdekin's representation of both the patriarchal and matriarchal world order and discusses her quest for the utopian impulse and constructive social change.
\end{abstract}

KEY WORDS: Katharine Burdekin, gender politics, hope, utopias, dystopias

\section{ROLES INVERTIDOS EN THE END OF THIS DAY'S BUSINESS DE KATHARINE BURDEKIN: UN ORDEN SOCIAL UTÓPICO-DISTÓPICO}

\section{RESUMEN}

Este artículo pretende introducir a la escritora británica, Katharine Burdekin, como escritora de ficción especulativa, y también tratar críticamente su utopía/distopía literaria, The End of This Day's Business $(1935,1989)$. Para entender la preocupación de Burdekin con el futuro y también su impulso utópico, hace falta información biográfica y una referencia a su otra obra notable, Swastika Night (1937). Este artículo presenta un enfoque analítico de la interconexión entre la política de género, la producción y la comunicación del conocimiento, y la práctica del poder en el orden mundial imaginado. Se trata sobre su representación de los órdenes mundiales patriarcales y matriarcales, y sobre su búsqueda de un impulso utópico y un cambio social constructivo.

PALABRAS CAVE: Katharine Burdekin, política de género, esperanza, utopías, distopías 


\section{KATHARINE BURDEKIN AS A WRITER OF SPECULATIVE FICTION}

More's text as a source for international scholars and writers has a huge influence over the British writer, Katharine Burdekin in her imagination of alternative socio-cultural and socio-political orders. Before dealing with her novel, it is useful to give brief biographical information about the writer, who deserves more critical evaluation and recognition ${ }^{1}$. Katharine Burdekin (July 1896 - August 1963) was born as Katharine Penelope Code. She wrote under the pseudonym Murray Constantine and also used the name Kay Burdekin in order to not reveal her female identity. However, Daphne Patai ${ }^{2}$, a professor in the Department of Languages, Literatures, and Cultures at the University of Massachusetts, Amherst, disclosed Murray Constantine's identity as Katharine Burdekin during in the 1980s.

Burdekin was born in Spondon, Derbyshire as the youngest of four children to an upper-middle class family. Her father was engaged with the family estate, whereas her mother's education came to a halt when she was thirteen. A governess initially educated Burdekin at home until the age of eleven or twelve in Cheltenham. Later on, she attended Cheltenham Ladies' College as a day student from 1907 until 1913, whereas her brothers attended Cheltenham College. At Cheltenham, girls were trained to contribute to national defense in line with the formation of Red Cross detachment.

Although Burdekin wanted to attend Oxford like her brothers, her parents did not allow it. In May 1915, she married Beaufort Burdekin, an Australian barrister and Olympic rower. During the time her husband served in the war, she took part in a Voluntary Aid Detachment at the army hospital situated on the Cheltenham Racecourse. Their two daughters were born in 1917 and 1920. In 1920, she moved to Sydney with her husband and children. Her writing career started in Australia. Her first novel, Anna Colquhoun was published in London in 1922. Her marriage ended in 1922, and she moved to Cornwall with her children to live with her mother and sister. She then concentrated on writing novels to a great extent, and started using the pseudonym Murray Constantine in 1934.

She wrote more than twenty novels (until 1956), short stories, poems and plays. She chose Murray as a family name, and Constantine after a village in Cornwall, as Daphne Patai explains (The End of This Day's Business, Afterword 165). She was very prolific in the 1920s, and especially in the 1930s. Some of her novels include The Reasonable Hope (1924), St. John' Eve (1927), The Burning Ring (1927), The Rebel Passion (1929), Quiet Ways (1930), Proud Man (under the pseudonym Murray Constantine, 1934), The End of This Day's Business (1935, 1989), Swastika Night (1937), and Venus in

\footnotetext{
${ }^{1}$ Although Katharine Burdekin is a known author in the field of Utopian Studies, she deserves more international recognition as a writer of speculative fiction.

${ }^{2}$ Daphne Patai is a very significant source for those who are planning to focus on Katharine Burdekin since she has written substantially on Burdekin and her texts.
} 
Scorpio (1940). In 1955, she was expected to die due to aneurysm, but managed to live eight more years in her home in Suffolk until she died in August 1963.

Burdekin's dystopian novel, Swastika Night, which is compared to George Orwell's Nineteen Eighty-Four (1949) has gained inter/national recognition by critics since Burdekin foreshadowed the extermination of the Jews by the Nazi ideology. The novel, which facilitates "a plurality of subjects [and perspectives] in the reading process," presents a world after 700 years of Nazi domination, governed by two empires, the Nazi Germany and the Japanese Empire ${ }^{3}$. The German Empire holds Europe and Africa and the Japanese Empire holds Asia, Australia, and the Americas. Hitler is worshipped as God in the Nazi Empire, and supernatural connotation is attached to his birth: «In God the Thunderer... and in His Son our Holy Adolf Hitler, the Only Man. Who was not begotten, not born of a woman, but Exploded!» ${ }^{4}$. This indoctrination rejects any alternative interpretations or possibilities, insisting on the unquestionable association of knowledge and/as truth in the extant Nazi order.

The indoctrination therefore produces a strictly hierarchical society and reduces women to mere breeders in a degrading manner. There arises a clash between the regime and the story's two main characters, Hermann and Alfred, who gain more awareness of how the order implements social engineering. Alfred struggles through his rebellion to topple the tyrannical regime, and the dominant social structure. $\mathrm{He}$ ultimately dies, but his rebellion against the dynamics of the Hitlerian society, with Hermann's and the old Knight's help, becomes pivotal in exposing the sides of this epistemological war. In this novel, which illustrates "social regression and extreme misogyny," women are silenced and denied the right to speak their mind, which ends in their total social and cultural exclusion ${ }^{5}$. In this sense, the novel becomes a "powerful feminist critique of patriarchal ideology, Nazism and totalitarianism" due to "awareness of regime's gender politics" (Baccolini 2000, 19). However, Burdekin projects a completely opposite social order by reversing gender roles in The End of This Day's Business, in which women are the leading group and men are silenced and denied the right to express their views.

\footnotetext{
${ }^{3}$ George McKay, "Metapropaganda: Self-Reading Dystopian Fiction: Burdekin's 'Swastika Night' and Orwell's 'Nineteen Eighty-Four',' Science Fiction Studies 21-3 (1994): 302-314, 311.

${ }^{4}$ Katharine Burdekin, The End of This Day's Business (New York: The Feminist Press as the City University of New York, 1989), 6.

${ }^{5}$ Geoffrey Winthrop-Young. "The Third Reich in Alternate History: Aspects of a Genre-Specific Depiction of Nazi Culture," The Journal of Popular Culture 39-5 (2006): 878-896, 885. doi:10.1111/j.15405931.2006.00310.x
} 


\section{A CRITICAL APPROACH TO THE END OF THIS DAY'S BUSINESS (1935)}

Burdekin as a pacifist writer does not resort to violence in her utopian/dystopian projections of alternative world orders. Instead, she employs dialogue and replaces action with more intellectual sophistication and contemplation. She depicts an epistemological clash between men and women, and individual and the state. Her main concern is to highlight gender inequality rather than illustrate women as the mere power holders. Her utopian climax is therefore a world order where both men and women do not oppress each other or use power to prioritize one group over the other. Her novel, The End of This Day's Business is about her critical engagement with gender politics, epistemological superiority, and power politics in a possible transformational journey to yet another would-be utopian world of complete gender equality. This article therefore aims to render a critical discussion of these problematic issues with specific references to The End of This Day's Business, which will hopefully be conducive to the extant critical studies on Burdekin and her works.

The novel was written in 1935, but was published only in 1989. It is set in a distant future, namely the year 6250 followed by four thousand years of women rule. Women as the ruling group are given the opportunity to express their views and to be informed about historical memory, whereas men are deprived of historical knowledge leading them to believe in their inferiority. The experiences of the main characters in the novel, Grania Carlasdaughter, Neil Carlason, Carla and Anna Karenstochter reflect the nature of the system, which has brought peace and an ideal order to the envisioned society. The main story revolves around Grania's incessant endeavors to awaken Neil to the reality of the ideological doctrine in an effort to equip him with historical awareness and to alter the feeling of inferiority. However, when her eventual goal unfolds, she is impeached for treason, and sentenced to capital punishment by dog poison. Both Grania and Neil commit suicide, hoping for change: «I'll say you are the first man of the new world that's to come after us» ${ }^{6}$.

The texture of the society is molded through rigid social and political norms. For example, marriage does not exist. Men know their mothers, but not their fathers. Men do not live with women unless they are boys. Women of two or three live together in a house, whereas men of five or six live together. Self-murder is encouraged for the stability and maintenance of the social order. Men of old age are killed if they are in poor health. A famous dancer or athlete kills himself or herself in senility. Weak men who are not accepted by both sexes are also known to commit suicide. Men who are crippled in accidents are emboldened to self-destruct.

Further, jealousy and obsessive possession are excluded in sexual relationships. Language competency empowers women, as Latin is the unique, secret language of

\footnotetext{
${ }^{6}$ Katharine Burdekin, The End of This Day's Business, 158.
} 
women and thus not taught to men. Women's leisure activities also demonstrate their social seclusion from men due to their engagement with swimming and walking. The fact that the regime interests itself in practicality and the concrete practical outcome becomes the reason why pure science, physics, and mathematics have not developed. This is in stark opposition to the studies of anatomy and biology, the science of sexual psychology, and the study of the mind, which have substantially improved as women are mainly concerned with health and life expectancy.

Burdekin presents a panopticonic society in her narrative with a view of accomplishing the desired utopian order, which later on engenders controversy and insurrection. Strict punishment plays a significant role in maintaining the order so citizens do not break its normative codes. Correspondingly, politicization is not permitted since the regime considers politicized individuals as a possible threat to its monolithic power. The ruling body does not allow critique against the official institutions of the state in order to not weaken its authority. Women are not allowed to plot against one another, lie to each other, or to indicate sex jealousy in the existence of other men. They are not allowed to mock men or to tease them. Similarly, breaking a sworn promise or oath to a man by a woman is regarded as a political conspiracy and accordingly, is punished harshly. It ends in the loss of public name, fame, honor, and death by dog-poison.

Educational politics becomes influential in shaping the ideological doctrine of female chauvinism and silencing boys and men. Manipulative education policy produces the division of gender roles starting at an early age, which conditions both sexes to a specific set of normative ethics. Both men and women learn to adopt these ingrained notions and values by integrating standardized behaviors into their daily lives. This indoctrination suppresses male violence and endows strong will and reason to women, especially in terms of having a complete control over their bodies. Some of these practices are narrated in a utopian mood over the course of the novel; however, its stern structure does not leave room for flexibility and transformational change, which might lead to a more ideal social organization. In line with the educational strategy, girls are put into boarding schools at eight years old to break the bond between a mother and daughter for their progress into maturity. They are taught geography, mathematics, hygiene, anatomy, art, literature, music, and other languages.

Boys are not allowed to leave their mothers until fourteen. Then, they are sent to boarding schools with other boys. They are taught hygiene, elementary physiology, geography, cleaning, and cooking. Men are denied the right to read books and masculine literature is destroyed in order to obstruct male curiosity and cultivation of the male mind. They do not learn about the past or the former patriarchal order as «[h]istory, its knowledge, and memory are ... dangerous elements that can give the 
dystopian citizen a potential instrument of resistance» ${ }^{7}$. Although they are not exploited in an abusive manner (they can keep their money to themselves, enjoy sexual freedom and are not the victims of violence, as opposed to the practices of the former patriarchal reign of men), their minds are enslaved and encaged, which becomes problematic for Grania. War-pictures are collected and not shown to men. However, they are encouraged to fight, to wrestle, and to box with bare hands to purge themselves of wanton violence and vandalism. Women do not allow men to develop sufficient will and psyche. Likewise, nationalism, wars, and religious pressure do not exist. Burdekin's narrative presents a number of utopian elements which seem emancipatory and flawless, but it brings along its own predicament related to gender, power and experiential transformation into a more ideal order.

Burdekin's text problematizes gender politics and the inferiority and/or superiority complex. Burdekin illustrates maintenance of a peaceful ${ }^{8}$ order through subordination of men and the rule of women without war and violence: «[T]he subjection of men by women was not an accidental and not-understood thing... it was a cold, logical and slow process, passed from Mother to daughter, and spreading over some two hundred and fifty years» ${ }^{9}$. Women manage to maintain the utopian structure in a pacifist manner for about four thousand years at the expense of the suppression of men without resorting to coercive impositions and physical violence.

However, this seemingly peaceful order brings forward some questions, which hint at certain dystopian realities for other characters in the novel: Does women's rule eventually bring happiness to the whole society? Is happiness achieved? How does manipulative epistemology affect citizens? What is prerequisite for an ideal world order? Is it possible to have a flawless utopia? Burdekin ultimately does not justify the prioritization of one group over the other since her protagonist, Grania, challenges and attempts to subvert the order. Her probable answer to the problem of gender inequality thus vitiates the complex of supremacy with a direct critique of male / female chauvinism. Nonetheless, it is worth stating that Burdekin's ultimate perspective implies a utopian impulse in the face of the extremist regimes in the 1930s in Europe, especially the rise of Hitler to power in Germany through its open-ended structure.

Burdekin's portrayal of female superiority against male inferiority does not idealize or perfect the social order. The female protagonist endeavors to reveal the

\footnotetext{
${ }^{7}$ Raffaella Baccolini. "“A useful knowledge of the present is rooted in the past': Memory and Historical Reconciliation in Ursula K. Le Guin's The Telling," in Dark Horizons: Science Fiction and the Dystopian Imagination, eds. Raffaella Baccolini and Tom Moylan (New York \& London: Routledge, 2003), 113-134, 115.

8 The word "peaceful" gains importance within the context of Grania's resistance against the system since a four-thousand-year order without violence and war does not satisfy the protagonist. Hence, peace or a peaceful order in the novel leads to a chaotic consequence for the character.

${ }^{9}$ Burdekin, The End of This Day's Business, 91.
} 
historical memory and factual history to her son, Neil, despite the strict punishment imposed by the system, which becomes "an epistemological journey of a particular kind" ${ }^{10}$. Grania as a rebellious individual «reclaims a suppressed and subterranean memory that is forward-looking in its enabling force, liberating in its deconstruction of the official story and its reaffirmation of alternative ways of knowing and living in the world $»^{11}$. She strives to display lack of love and happiness in this mechanized and callous world. Neil, who is 24 years old, learns about the dispositions of men and women. He accordingly attaches specific properties to both sexes such as "the noisy physical tumult of the men and the quietness, the cold, spiritual strength and pride of the women" ${ }^{\prime 2}$. Neil's questioning mind gradually intensifies since he is already ashamed of his sex and more revisionary epistemology is brought to his consciousness: «It's because you really are, inside you, ashamed of your sex. Ashamed of those portions of you which most markedly differ from women's bodies ${ }^{13}$.

The state does not manage to intercept Grania's quest for undistorted knowledge and implementation of gender politics in a new light until her physical death. She launches an epistemological warfare against gender discrimination as she is conscious that «any human being can be kept in moral slavery by early inculcation of sex-shame» ${ }^{14}$. This critical perspective which attests to the relativity of truth / knowledge reinforces Daphne Patai's stress on the significance of knowledge and dignity in Burdekin's vision: «Hence Grania's belief that dignity and knowledge must be restored to men, that this path alone represents the hope of the future» ${ }^{15}$.

Grania's revolutionary vision challenges the power of the state, and results in her trial by Anna Karenstochter, the General Secretary for Europe for seven years, in Munich, Germany. Her conversation with Anna, who has an emotional relationship with Grania and Neil, highlights the inflexible texture of the order and Grania's keen self-awareness. Grania indicates five war pictures from the former patriarchal order to Neil, tells him about wars, fascism, patriotism, death hysteria, the Fascist cult, the Communist rule, and the Secret Society of Women. All these historical and social realities shake the implanted, fixed mindset of Neil and raise Grania's hopes for social transformation.

In addition to Neil, Grania challenges the official agent, Anna's views on the order through a critical discussion of governance, gender equality and happiness: «I 6.

${ }^{10}$ Jennifer Wagner-Lawlor, Postmodern Utopias and Feminist Fictions (Cambridge: Cambridge UP, 2013),

11 Tom Moylan, Scraps of the Untainted Sky: Science Fiction, Utopia, Dystopia (Colorado: Westview Press, 2000), 149-50.

${ }^{12}$ Burdekin, The End of This Day's Business, 27.

${ }^{13}$ Burdekin, The End of This Day's Business, 40.

${ }^{14}$ Burdekin, The End of This Day's Business, 90.

${ }^{15}$ Daphne Patai. “Afterword," in The End of This Day's Business, Katharine Burdekin (New York: The Feminist Press as the City Uni of New York, 1989), 187. 
want all men to have more spirit» ${ }^{16}$. Her wish to create more individuals rather than types without unique properties is not met with sympathy or empathy since Anna does not regard it as realistic. Anna's homosexual connection to Grania does not deter her from realizing her official responsibility, although it burdens her with the feelings of pity and remorse. Grania in a way instills her deviant ideology into Anna's mind by stretching her personal limits since she believes that the dominant ideology contains «spurious identification... deception, self-deception» ${ }^{17}$. She touches on her concern about gender inequality, men's underdeveloped minds, and the world without love and happiness, which makes Anna question her own views.

Anna as a figure in charge becomes the seed of hope in Germany for Grania, who confesses their loss in England: «Anna will go on with it. And far better than we could. She's got much more brain, and caution and energy and thoroughness... She's got into a perfectly inevitable psychological tangle... Anna will see straight and know what she really knows now ${ }^{18}$. Grania's conversations with both Neil and Anna are instrumental in her uprising against the dogmatic nature of the female rule and against its role in a future world of equality and self-esteem. She therefore becomes the main agent through whom Burdekin critiques the lacking aspects of both patriarchal and matriarchal social order to attain a more utopian society by «offering radical challenges to the status quo, not reinforcing or reconstructing it» $\rangle^{19}$.

Burdekin in her handling with gender politics attaches great importance to selfesteem, which leads the individual to self-actualization in Maslow's hierarchy of needs. It is a precondition for both sexes to reach an ideally equal society without ignominy, manipulation, suppression, domination, and obliteration. Grania thus gradually awakens Neil to the unsuppressed factual and historical reality of the world by touching on the past of men and the previous violent patriarchal social order as selfesteem is what takes an individual to maturity, sophistication and reasoning:

This is a safe world, nothing can happen against our will, and we're safe undestructive people. But it's a coward's world... It's not right to hold a grudge for four thousand years, and from that grudge and that cowardice to deprive half the human race of its human right to grow. We call ourselves mature, and we say that in the race's maturity women must rule. But no race can ever be mature while one sex is infantile ${ }^{20}$.

Her transformational journey reveals the deficiencies of the depicted order, and leads her to her quest without segregation through her belief in Anna, Neil, and

${ }^{16}$ Burdekin, The End of This Day's Business, 139.

${ }^{17}$ Terry Eagleton, Ideology: An Introduction (London \& New York: Verso, 2007), 232.

${ }^{18}$ Burdekin, The End of This Day's Business, 157.

${ }^{19}$ David Halphin, Hope and Education: The role of the utopian imagination (London: Routledge Falmer, 2003), 37.

${ }^{20}$ Burdekin, The End of This Day's Business, 143. 
some other men. Realizing oneself thus becomes the main focus-point of Burdekin's sex-role reversal novel, which «affirms the hope that the species will evolve, that the remnants of the Childhood Age, still extracting their due, can and will be transcended $»^{21}$.

The title of Burdekin's novel reflects the protagonist's yearning for a more utopian social order, and her ensuing revolt against the autocratic regime. It refers to Grania's punition and her death as a result of her felony, the goal of which is to shape new free individuals as opposed to the men of the extant system. It is a reference to the lines of Brutus in Shakespeare's tragedy, Julius Caesar:

Why, then, lead on. O, that a man might know

The end of this day's business, ere it come:

But it sufficeth, that the day will end,

And then the end is known. Come, ho! away!22

Grania as the female Brutus who is conscious of the outcome of her guilt does not shy away from her goal. The end of her day's business is capital punishment, but she does not lose her utopian impulse for the future about the possibility of drastic social transformation into a new world order, free from repression and exploitation: «[T] he end will come, in God's time, not mine. And in God's time, not mine, the End of my day's business will be known. But not by me» ${ }^{23}$. These words and the openended structure of her narrative can be interpreted as reflecting Burdekin's utopian hope for the future, but she also leaves it to the readers' imagination as to what kind of a new world order to envision next.

\section{CONCLUSION}

In conclusion, Grania's incessant efforts to transform Neil into a new man, the first man of the new world to come, should be interpreted as productive and positive at the expense of Neil's death by dog-poison. Neil's new state of mind allows him critical judgment and courage to self-decide rather than to submit. He drinks the dogpoison; his self-sacrifice is an indicator of prospective hope for a future society of equality, as Neil takes pride in his fearless attempt to be the first man of the new world that is to come after Grania and Neil. This demonstrates his transcendental move in the face of a repressive governing structure.

\footnotetext{
${ }^{21}$ Daphne Patai. “Afterword," in The End of This Day's Business, Katharine Burdekin (New York: The Feminist Press as the City Uni of New York, 1989), 188.

22 William Shakespeare, Julius Caesar, ed. H. M. Hulme (London: Longmans, Green, 1959), Act V. Scene I. 125-28.

${ }^{23}$ Burdekin, The End of This Day's Business, 29.
} 
In this study, I have attempted to introduce Katharine Burdekin as a significant utopian writer with a brief reference to her well-known novel, Swastika Night, and to critically deal with her long-forgotten novel, The End of This Day's Business. Burdekin deserves more critical appreciation and academic research into her works as a writer endowed with strong imagination and unique eloquence. Her insight into the future and her foreshadowing faculty became an inspirational source for the writers of the following decades including George Orwell. Burdekin attaches great significance to gender politics, knowledge production, and its relation to power practice in her novel, The End of This Day's Business. This thematic critical analysis in this light hopefully contributes to the existing academic studies on Burdekin's text by providing new perspectives into this novel and promotes its inter/national reception by the critics and the readers.

In this vision, what is remarkable is that she does not represent one group as merely white and innocent, but she spotlights the fallacious arguments of both the patriarchal and the matriarchal rules and challenges our established notions: «The great utopia startles... It is not a sleepy or bizarre vision but one that satisfies a hunger or stimulates the mind and the body to the recognition of a new potentiality ${ }^{24}$. Burdekin elucidates and signals such a new potentiality in that it is only possible to accomplish yet another utopia by molding a society without sex, class, or any other types of antagonism. This eventual utopian impulse reflects Burdekin's staunch belief in unfading hope through pacifist means, and increases the utopian hope for a more ideal and equal society despite the contextual catastrophic conjuncture of the period.

\section{BIBLIOGRAPHY}

Baccolini, Raffaella. "'A useful knowledge of the present is rooted in the past': Memory and Historical Reconciliation in Ursula K. Le Guin's The Telling," in Dark Horizons: Science Fiction and the Dystopian Imagination, eds. Raffaella Baccolini and Tom Moylan (New York \& London: Routledge, 2003), 113-134.

---. "Gender and Genre in the Feminist Critical Dystopias of Katharine Burdekin, Margaret Atwood, and Octavia Butler," in Future Females, The Next Generation: New Voices and Velocities in Feminist Science Fiction Criticism, ed. Marleen S. Barr. (Lanham: Rowman \& Littlefield, 2000), 13-34.

Burdekin, Katharine, The End of This Day's Business (New York: The Feminist Press as the City University of New York, 1989).

---, Swastika Night (London: V. Gollancz, 1937).

${ }^{24}$ Frank E. Manuel and Fritzie P. Manuel, Utopian Thought in the Western World (Cambridge, Massachusetts: The Belknap Press of Harvard UP, 1979), 29. 
Eagleton, Terry, Ideology: An Introduction (London \& New York: Verso, 2007).

Halphin, David, Hope and Education: The role of the utopian imagination (London: Routledge Falmer, 2003).

Manuel, Frank E., and Fritzie P. Manuel, Utopian Thought in the Western World (Cambridge, Massachusetts: The Belknap Press of Harvard UP, 1979).

McKay, George, "Metapropaganda: Self-Reading Dystopian Fiction: Burdekin's 'Swastika Night' and Orwell's 'Nineteen Eighty-Four',' Science Fiction Studies 21 3 (1994): 302-314.

Moylan, Tom, Scraps of the Untainted Sky: Science Fiction, Utopia, Dystopia (Colorado: Westview Press, 2000).

Patai, Daphne. "Afterword," in The End of This Day's Business, Katharine Burdekin (New York: The Feminist Press as the City Uni of New York, 1989).

Shakespeare, William, Julius Caesar, ed. H. M. Hulme (London: Longmans, Green, 1959).

Wagner-Lawlor, Jennifer, Postmodern Utopias and Feminist Fictions (Cambridge: Cambridge UP, 2013).

Winthrop-Young, Geoffrey. "The Third Reich in Alternate History: Aspects of a Genre-Specific Depiction of Nazi Culture," The Journal of Popular Culture 39-5 (2006): 878-896. doi:10.1111/j.1540-5931.2006.00310.x

Recibido: 16 de marzo de 2017 Aprobado: 9 de octubre de 2017 